\title{
The Effect of Prenatal Massage Towards Anxiety Level of Third Trimester Pregnant Women in The Work Area Of Cibeureum Public Health Center Tasikmalaya 2019
}

\author{
Eva Ardianti ${ }^{1)}$; Sinar Pertiwi2); Etin Rohmatin ${ }^{3)}$ \\ Evardianti19@gmail.com
}

\begin{abstract}
Background: During pregnancy, most women experience psychological and emotional changes, it often comes up in the third trimester. Anxiety itself will have a negative impact on pregnant women to delivery, such as the fetal nervous and hindering growth, weakens the uterine muscle contraction, and others. One way to overcome anxiety in pregnancy with non-farmokologi method is prenatal massage.

Methods: The study design used was pre-experimental research design with one group pretest posttest. Sampling in this research using purposive sampling technique with a sample size of 30 people. Pretest and posttest data retrieval using a measuring instrument HARS Scale (Hamilton Rating Scale for Anxiety). The data were analyzed using univariate and bivariate using Spearman Correlation Test.

Result: Obtained results correlation value 0.769 , it shows that the correlation is very strong with 0,000 pvalue ( $\rho$ value $<0.05$ ).

Conclusion: Thus prenatal massage was effective to reduced the anxiety level of third trimester pregnant women
\end{abstract}

Key Word: prenatal massage; anxiety; pregnant; third semester

1,2,3) Health Polytechnic of Tasikmalaya Midwifery Department

Background. During pregnancy most women experience psychological and emotional changes, it often comes up in the third trimester (Rukiah et al., 2009). Anxiety during pregnancy can be caused by physical changes, fear of childbirth and parenting role transition (Varney, 2010). Anxiety itself will have a negative impact on pregnant women during pregnancy to delivery, such as the fetal nervous and hindering growth, weakens the uterine muscle contraction, and others (Novitasari, Budiningsih and Mabruri, 2013). Not only reducing the levels of anxiety and mother's preparation process to face a labor with pharmacology method but also there are methods of non-pharmacological such as relaxation, breathing techniques, movements and position changes, massage, hydrotherapy, hot / cold therapeutic, music, guided imagery, accupresure, and aroma therapy.

One way to overcome anxiety in pregnancy with non-pharmacology method is prenatal massage. Prenatal Massage is a massage for pregnant women consist of a wide variety of appropriate massage techniques and to treat common discomfort of pregnancy (Stillerman, 2008). As in a study conducted by (Sari and Pantiawati, 2013) regarding "Perbandingan Teknik Massage Dan Terapi
Musik Terhadap Penurunan Kecemasan Pada Ibu Bersalin Primipara Di Kecamatan Brebes Tahun 2013" ("Comparison of Massage Techniques and Music Therapy Against the Anxiety Alighting on the Labor of Primiparas Woman in Brebes District 2013"). Results showed that the technique of massage with $p$ value $<a(0.000<0,05)$, and music therapy with $p$-value $<a(0,000<0: 05)$, thus the massage technique is more effective in reducing anxiety levels as compared to the value of music therapy

Methods. The method used was preexperimental research design with one group pretest posttest. This research was conducted in Cibeuruem Public Health Centre, Tasikmalaya City on January-March 2019. The samples in this research using purposive sampling technique with a sample size of 30 people. Pretest and posttest data retrieval using a measuring instrument HARS Scale (Hamilton Rating Scale) for Anxiaty. Giving 4x Prenatal Massage was done in 2 weeks for 20 minutes. The data were analyzed using univariate and bivariate using Spearman correlation test

Research and Discussion. This research has been conducted in Cibeureum Public Health Centre starts from January to March 
2019. The sample in this study were 30 pregnant women with gestational age $>32$ weeks. The results of the study are as follows:

Table 1. Distribution of Anxiety Levels In the Third Trimester Before Prenatal Massage in Cibeureum Public Health Centre, Tasikmalaya 2019

\begin{tabular}{clcc}
\hline No & Anxiety scale & $f$ & $\%$ \\
\hline 1 & Not Worried & 1 & 3.3 \\
2 & Mild Anxiety & 22 & 73.3 \\
3 & Medium Anxiety & 7 & 23.3 \\
4 & Severe Anxiety & 0 & 0 \\
& Total & 30 & 100 \\
\hline
\end{tabular}

Based on the research that had been done on the level of anxiety in the third trimester of pregnant women were obtained before given prenatal massage, maternal anxiety levels with mild anxiety category as many as 22 people (73.3\%), severe anxiety as many as 7 people $(23.3 \%)$. The factors that most influence the anxiety in this study was due to the discomfort that felt by the mother.

In a study conducted by (Damarsanti, Anggraini and Setianingsih, 2018) showed that the results of the total respondents are 36 third trimester pregnant women before intervention, 16 people suffered mild anxiety and 16 people suffered medium anxiety. Factors that may affect anxiety appears in third trimester pregnant women due to the discomfort felt, previous traumatic deliveries, and the mothers readiness towards the estimated labor day.

Table 2. Distribution of Anxiety Levels in the Third Trimester After Prenatal Massage in Cibeureum Public Health Centre, Tasikmalaya 2019

\begin{tabular}{cccc}
\hline No & Anxiety scale & F & $\%$ \\
\hline 1 & Not Worried & 11 & 36.7 \\
2 & Mild Anxiety & 18 & 60.0 \\
3 & Medium Anxiety & 1 & 3.3 \\
4 & Severe Anxiety & 0 & 0 \\
& Total & 30 & 100 \\
\hline
\end{tabular}

Based on the research that had been done on the level of anxiety in the third trimester of pregnant women, after prenatal massage treatment, the results obtained decrease in anxiety levels with mild anxiety category as many as 18 people (36.7\%), severe anxiety as much as $1(3.3 \%)$ and there is no anxiety as many as 11 people (60\%).

Results of research conducted by (Sukmaningtyas and Windiarti, 2016), showed that out of 15 respondents were given a massage endorphine mostly mild anxiety levels as much as $46.7 \%$. The result showed that the respondents were given endorphine massage mostly mild anxiety levels, because massage is one of the non-pharmacological therapy to reduce or alleviate pain during delivery

Table 3. The Effect of Prenatal Massage Towards the Anxiety Level of Pregnant woman in The Third Trimester In Cibeureum Public Health Centre Tasikmalaya, 2019

\begin{tabular}{cccc}
\hline Commentary & $\mathbf{N}$ & $\begin{array}{c}\text { Correlatio } \\
\mathbf{n}\end{array}$ & $\begin{array}{c}\boldsymbol{\rho} \\
\text { Value }\end{array}$ \\
\hline $\begin{array}{c}\text { Before Prenatal } \\
\text { Massage }\end{array}$ & 30 & & \\
$\begin{array}{c}\text { After Prenatal } \\
\text { Massage }\end{array}$ & 30 & .769 & 0,000 \\
\hline
\end{tabular}

Statistical test results obtained the value of correlative trials with Spearman test is 0.769 , it was showed that the correlation was very strong with an unidirectional relationship between both variables. The $\rho$ value is 0,000 it showed that the pvalue less than $\alpha(0.05)$.

It was supported in a study conducted by (El-Hosary, Abbas Soliman and El-Homosy, 2016) with the title "Effect of Therapeutic Massage On Relieving Pregnancy Discomforts" obtained the results, after being given treatment there was a degradation average with $\rho$ value $=0,000$, so there was a reduction after given massage.

Conclusion and Suggestions. Based on research's results could be concluded that there was a prenatal massage effect on the level of anxiety third trimester pregnant women in the Cibeureum Public Health Centre with correlation value : 0.769 - indicating that the correlation was very strong and the value of $(\rho=0.000)$. Prenatal massage could be done in third trimester pregnant women

Acknowledgements. Thanks to the researchers say to all those who have helped in completing this research.

\section{References}

Damarsanti, P., Anggraini, R. and Setianingsih (2018) 'Pengaruh Rendam kaki dengan Air Hangat terhadap Tingkat Kecemasan pada Ibu Hamil Trimester III di Puskesmas Pegandon Kendal', NURSCOPE, 4(1), pp. 1-10. Available at: file://C:/Users/HP/Downloads/2866-65031-SM.pdf. 
El-Hosary, E., Abbas Soliman, H. F. and ElHomosy, S. (2016) 'Effect of Therapeutic Massage on Relieving Pregnancy Discomforts', IOSR Journal of Nursing and Health Science, 05(04), pp. 57-64. doi: 10.9790/1959-0504025764.

Novitasari, T., Budiningsih, T. E. and Mabruri, M. I. (2013) 'Keefektifan Konseling Kelompok Pra-Persalinan untuk Menurunkan Tingkat Kecemasan Primigravida Menghadapi Persalinan', Developmental and Clinical Psychology, 2(2), pp. 62-70. Available at: https://journal.unnes.ac.id/sju/index.php/d cp/article/view/2578.

Rukiah, A. Y. et al. (2009) Asuhan Kebidanan I (Kehamilan). Jakarta: Trans Info Media (TIM).

Sari, D. K. and Pantiawati, I. (2013) 'Perbandingan Teknik Masase dan Terapi Musik terhadap Penurunan Kecemasan pada Ibu Bersalin Primipara di Kecamatan Brebes Tahun 2013', Bidan Prada: Jurnal Ilmiah Kebidanan, 4(01), pp. 1-15. Available at: http://ojs.akbidylpp.ac.id/index.php/Prada/ article/view/33.
Stillerman, E. (2008) Prenatal Massage; $A$ Textbook of Pregnancy, Labor and Postpartum Bodywork. St Louis Missouri: Mosby. Inc.

Sukmaningtyas, W. and Windiarti, P. A. (2016) 'Efektivitas Endorphine Massage terhadap Tingkat Kecemasan Ibu Bersalin Primippara', Bidan Prada; Jurnal IImiah Kebidanan, 7(1), pp. 53-62. Available at: https://ojs.akbidylpp.ac.id/index.php/Prad a/article/view/141/129.

Varney, H. (2010) Buku Ajar Asuhan Kebidanan. 4th edn. Jakarta: EGC.

A

